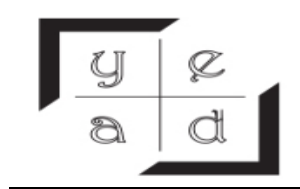

\title{
ÜCRET FARKLILIKLARINA NEDEN OLAN FAKTÖRLER VE İŞGÜCÜ PIYYSASINDA TABAKALAŞMA: ANKARA İLİ İNŞAAT SEKTÖRÜ ÜZERINE BİR ALAN ARAŞTIRMASI
}

\section{Doç.Dr. Hacer Simay KARAALP-ORHAN* iD}

\section{Deniz AKSOYLU *}

ÖZ

Adil bir gelir dă̆glımının sağlanması cari ücret seviyesinin oluşmasını gerekli kllmaktadır fakat işgücünün sahip olduğu özelikler, işin niteliği ve ücret yapısından kaynaklanan faktörlere ilaveten işgücü piyasasındaki gözlenen tabakalı yapı aynı işe farklı ücret ödenmesine yol açmaktadır. İnşaat sektörü Türkiye'nin hizl gelişen ve katma değer yaratan sektörlerinden biri olmakla birlikte istihdam yaratma kapasitesi bakımından önem taşımaktadır. Fakat sektörde farklı vasıf ve niteliğe sahip birçok farklı meslek grubu, zayı fĕgitim istihdam ilişkisi ve ağır çalışma koşulları gözlenmektedir. Araştırma sonuçlarına göre ücret farkllliğına neden olan faktörler eğitim ve mesleki tecrübe (yaş) gibi işgücünün özelliklerinden olarak ortaya çıkmıştır. Büyük kurumsal firmada çalışanların taşeron firmada çalışanlara göre eğitim düzeyi, yaş ve mesleki tecrübesinin daha yüksek olduğu, daha yüksek ve düzenli ücret aldiğı, kariyer olanaklarının ve sosyal yardımların daha fazla olduğu buna karşın her iki gruptaki firmalarda sendikalaşmanın olmadığı tespit edilmiştir. Bu kapsamda ortaya çıkan ücret farklılıkları sektördeki tabakalı yapıyı ortaya koymaktadır.

Anahtar Kelimeler: Ücret Farklılı̆̆l, Isşgücü Piyasasında Tabakalaşma, İnşaat Sektörü

JEL Kodlart: J31, J42, L74

\section{FACTORS AFFECTING WAGE DIFFERENTIALS AND LABOUR MARKET SEGMENTATION: A FIELD STUDY ON CONSTRUCTION SECTOR IN ANKARA}

\begin{abstract}
Ensuring an equal distribution of income requires the formation of the current wage level however the workforce characteristics, working conditions and nature of work and wage structure and labour market segmentation also leads to wage differentials to the same job. Construction sector which has been one of the rapid growing and high value-added sectors in Turkey has also an

\footnotetext{
* Pamukkale Üniversitesi, İktisadi ve İdari Bilimler Fakültesi, Çalışma Ekonomisi ve Endüstri Bölümü, Kınıklı Kampüsü, 20070, Denizli, Türkiye, e-mail: skaraalp@pau.edu.tr

* Pamukkale Üniversitesi, Sosyal Bilimler Enstitüsü, Çalışma Ekonomisi ve Endüstri Bölümü ABD, Doktora Öğrencisi, email: deniz_aksoylu06@hotmail.com
} 
importance in terms of employment creation capacity. However, many different professions with different qualifications, the weak relationship between employment and education, heavy working conditions and low-cost production requirement is observed in the sector. The findings indicate that wage differentials are stemming from the characteristics of the workforce such as education and professional experience (age). It has been found that the employees of the large corporate firms have higher level of education, age and professional experience, higher and regular wages, more career opportunities and social benefits compared to those of the subcontractors, but no unionization is found in both groups. In this context, the wage differential reveals the labour market segmentation in the construction sector.

Keywords: Wage Differentials, Labour Market Segmentation, Construction Sector.

JEL Codes: J31, J42, L74

\section{GIRIŞ̧}

İşgücü piyasasını mal ve hizmet piyasalarından ayıran ve dolayısıyla işleyişinde farklılıklar ortaya çıkmasına neden olan birçok yapısal özellik bulunmaktadır. Bu bağlamda, işgücü piyasasına konu olan emeğin alacağı ücretin belirlenmesinde çeşitli farklılıklar ortaya çıkmaktadır. Klasik İktisat teorisinin aksine emek piyasasında tek bir denge ücreti belirlenememekte ve işgücü piyasasının en önemli değişkenlerinden birini ücret oluşturmaktadır. Neo-Klasik iktisatçılar ise ücretlerin eşit olması gerektiğini ileri sürerek, ücret farklılıklarının işin ve işgücünün özellikleri çerçevesinde açıklamaya çalışmıştır. Ücretler farklı sektörlerde, farklı mesleklerde, farklı işyerlerinde farklı işleri yapanlar arasında farklılaşırken, bazen aynı sektörde aynı işleri yapanlar arasında da farklılık göstermektedir. $\mathrm{Bu}$ bağlamda, işgücü piyasasındaki tabakalaşma da ücretler arasındaki farklılaşmayı etkilemektedir. Kurumcu iktisatçılar tarafindan yaygın bir şekilde kullanılan işgücü piyasasında tabakalaşma kavramı ile işgücü piyasasının çeşitli şekillerde tabakalaştığı ve çalışanların tabakalar arasında geçişinin zor olduğu kabul edilmektedir. Esnek olmayan işgücü piyasasında tekelci firmalar ve kurumsal düzenlemeler nedeniyle bazı çalışanların kendi istekleri dışında, daha düşük şartlarla donatılmış, ikincil piyasalarda çalışmak zorunda kalmaktadır. Tabakalı yapı gösteren işgücü piyasasının "içseldışsal" ve "birincil-ikincil" piyasalar olarak ayrılırken, işlerin "iyi iş" ve "kötü iş" olarak ayrılmasına neden olmaktadır. Böylece birincil sektörde çalışanların, ikincil sektörde çalışanlarla aynı sektörde olup aynı işi yapmalarına karşın daha yüksek ücret aldığı gözlenmekte ve ücretler arasında farklılıklar ortaya çıkmaktadır. Türkiye'nin en hızlı gelişen ve katma değer yaratan sektörlerinden biri olması ile birlikte istihdam yaratma kapasitesi bakımından önem arz eden inşaat sektörü farklı vasıf ve niteliğe sahip birçok farklı meslek grubunu kapsamaktadır. Bir taraftan yüksek nitelikli bir uzmanlaşmış işgücü, diğer taraftan yarı vasıflı, eğitim seviyesi düşük ve niteliğe sahip olmayan bir işgücü bulunmaktadır. Bununla birlikte, sektörde ana yüklenici ve altyüklenici (taşeron) olarak iş yapma teknikleri yer almaktadır. Kurumsal firma ve taşeron firma ayrımında ise en belirgin olarak ücret 
farklılıklarında ortaya çıkmaktadır. Aynı beşeri sermayeye sahip olmalarına rağmen ortaya çıkan ücret farklılıkları inşaat sektöründe tabakalı piyasa yapısının var olabileceği olgusunu yaratmıştır. $\mathrm{Bu}$ kapsamda bu çalışmada tabakalı işgücü piyasası çerçevesinde inşaat sektöründe ücret farklılığına neden olan faktörler ele alınarak aynı işi yapan fakat farklı firmalarda çalışan aynı mesleki statüdeki kişilerin farklı ücretler almasının nedenlerinin ortaya çıkarılmaya çalışılımıştır. Bu amaçla çalışma beş bölümden oluşmaktadır. Çalışmanın ikinci bölümünde, ücret kavramı ve ücret farklılığına yol açan faktörler, üçüncü bölümde tabakalaşma teorisi ele alınmıştır. Dördüncü bölümde, literatür çalışmaların özetlenmiş, beşinci bölümde Türkiye inşaat sektörüne ilişkin genel bilgiler verilmiştir. Alan araştırmasının yer aldığı altıncı bölüm sorasında çalışma sonuçlandırılmıştır.

\section{2. ÜCRET FARKLILIĞINA YOL AÇAN FAKTÖRLER}

Bir taraftan "insan emeğinin bedeli” olarak tanımlanan ücret (Işı̆̆ııçok, 2011: 3), diğer taraftan, adil bir gelir dağılımı ve sağlıklı bir toplum için, çalışanlara sosyal hasıladan emeği karşılığı ödenen faktör fiyatı olarak tanımlanmaktadır (Topalhan, 2013: 5). Bir ekonomide ücretler arasında ortaya çıkan farklılıklar uzun dönemde gerek ekonomik gerekse de sosyal sorunlara neden olmaktadır. Ekonomi literatüründe ücretler arasında farklılıklarına ilişkin A.Smith'in (1776) net avantajlar teorisinde ileri sürdüğü nedenler, Neo-Klasik iktisatçılar tarafından geliştirilerek farklı boyutlarıyla ele alınmıştır. Bu bağlamda ücretin belirlenmesine etkili olan temel faktörler "Işsü̈cünün özelliği”, "işin niteliği” ve “ücret yapısı” ndan kaynaklanan faktörler olmak üzere üç başlık altında incelenmiştir.

\section{1. İşgücünün Özelliğinden Kaynaklanan Faktörler}

Ücretlerin belirlenmesinin güç olmasının nedenleri arasında, emeğin çeşitliliği ve sahip olduğu farklı özellikler ve nitelikler yer almaktadır. Beşeri sermaye farklılıkları olarak da adlandırılan bu faktörler cinsiyet, medeni durum, yaş, eğitim düzeyi, mesleki tecrübe ve verimlilik olarak sıralanmaktadır. Ücret farklılığına neden olan demografik faktörlerin başında gelen "cinsiyet" işgücü piyasasında kadınlara yönelik yapılan ayrımcılıkların başında gelmektedir. Toplumsal cinsiyet eşitsizliği ya da bir başka deyişle cinsiyete dayalı iş bölümü temelinde kadınlara ve erkeklere biçilen roller nedeniyle kadınlar, erkekler ile aynı eğitim düzeyine ve mesleki kıdeme sahip olsalar bile sadece kadın olmalarından kaynaklı cinsiyetçi ücret ayrımına maruz kalmaktadırlar. Diğer taraftan medeni durum, özellikle evli kadınların işgücü piyasasına katılımını düşürmekte ve aldığı ücret düzeyini etkilemektedir. Özellikle düşük nitelikli ve düşük ücretli işlerde çalışan kadınlar, evlendikten sonra çalışmamayı tercih etmekte ya da çalışmaya ara vermektedir. Daha sonra işgücü piyasasına geri dönen kadınların daha düşük bir ücretle işe başlamasına neden olmaktadır. Bu durumu göz önünde bulunduran işverenler kadın çalışanlarına mesleki eğitim vermeyi tercih etmemekte ve dolayısıyla onların daha düşük beşeri sermaye donanımına sahip olmalarına neden olmaktadır (Durmaz, 2016: 39). Ücret farklı1ığına neden olan bir diğer faktör çalışanların yaşıdır. Özellikle emek yoğun işlerde istihdam edilecek kişi seçilirken taşıdığı niteliklerden ziyade fiziki kuvveti ve yaşça genç olması ön 
planda tutulurken, sermaye yoğun sektörlerde yaştan ziyade kıdem öne çıkmaktadır. Emek yoğun sektörlere göre, sermaye yoğun sektörlerde yaş ilerledikçe ve kıdem arttıkça piyasaya girişin daha kolay olduğu görülmektedir (Murat ve Şahin, 2011: 57). Şöyle ki, işveren işe alırken işi bilen, tecrübeli ve belirli bir mesleki kıdeme sahip işçiyi yeni mezun ve tecrübesiz işçiye tercih etmektedir. İşveren tecrübesiz işçinin işi öğrenme, işe uyum sağlama ve verimli bir şekilde üretime katkı sağlama gibi süreçlerin maliyetlerine katlanmaktan ziyade tecrübeli işçiyi işe alarak, gerek işbaşında eğitim vermeyerek gerekse maddi ve zamansal birçok avantaj sağlayacaktır. Buna ek olarak işveren, tecrübeli işçinin mesleki kıdeminden edindiği başka yeteneklerinden de faydalanabilecektir. Ücret düzeyini etkileyen bir diğer faktör eğitim düzeyi yani beşeri sermeyedir. Gery Becker (1962) tarafından ortaya atılan Neo-klasik beşeri sermeye modeline göre bireylerin mesleki niteliklerini arttırmak için yapmış olduğu beşeri sermaye yatırımları ücretlerini arttıracaktır. Buna göre ücret farklılıkları bireylerin verimliliklerindeki farklılıklarla açıklanmaktadır. Emeğin verimliliğini ise eğitime yapılan yatırımlar belirlemektedir. Beşeri sermaye modelini ortaya atan Becker'a göre, kişilerin aldığı eğitimler (okul veya mesleki eğitim) verimliliklerini arttıracak, dolayısıyla bu yatırımlar gelir üzerinde senelerce etkili olacaktır. Ortalama olarak, daha eğitimli işçiler görece daha çok kazanç elde ederlerken, daha düşük eğitimliler görece daha düşük kazanç elde etmektedir. Yükseköğretime yapılan harcama ile ücret beklentisi de doğru oranda artmaktadır. Hipotetik olarak eğitim seviyesi yükseldikçe elde edilecek kazancın yükseleceği düşünülmektedir (Lordoğlu\&Özkaplan, 2007). Bu bağlamda, TÜİK 2014 Yılı Kazanç Yapısı Araştırması sonuçlarına göre, Türkiye'de eğitim seviyesi arttıkça özellikle kadınların yıllık ortalama brüt ücretlerinin ve kazançlarının arttı̆̆ görülmektedir (TÜiK, 2015). Diğer taraftan, ücret belirlenirken en önemli konulardan biri ücret ve alınan verimin birbirini dengelemesidir. Bir işletmede verimlilik düzeyi ne kadar yüksekse ücretlerin de aynı oranda yüksek olması beklenmektedir. Dolayısıyla işletmeler arasındaki verimlilik farkı ücret düzeylerinin de farklılaşmasına yol açmaktadır. Leibenstein, Akerlof, Katz ve Weiss tarafından geliştirilen etkin ücret teorisine göre, işçilere çeşitli nedenlerle piyasa ücretinin üzerinde bir ücret verilmesi durumunda, emek verimliliği artacak ve etkin ücret ödemeleri görünüşte emek maliyetlerini yükseltse de, bu yolla sağlanacak verimlilik artışları kar artışını da beraberinde getireceğinden bunu kolaylıkla telafi edecektir (Gündoğan\&Biçerli, 2008: 88). Dolayısıyla etkin ücret teorisi, işçilerin verimlilikleri ile ücretleri arasında pozitif bir ilişkinin olduğunu ifade etmektedir. Bu durumda, firmalar cari piyasa seviyesinin üzerinde ücret ödemeyi kabul etmektedirler ve firmanın ödediği yüksek ücretler, işçilerin verimlilik artışı ile sonuçlanmaktadır. (Katz, 1986:235).

\section{2. İşin Niteliğinden Kaynaklanan Faktörler}

İşin niteliği, sektördeki emek arzı, işyerindeki kariyer imkanı, işin kısa ya da uzun süreli olması, işin taşıdığ riskler ve sorumluluklar, mesleki prestij, firma büyüklüğü ve çalışma saatleri, işçinin sendikalı olup olmaması gibi işin niteliğine ve çalışma ortamına ilişkin faktörler ücretler arasında farklılığa neden olmaktadır. 
İşyerlerindeki fazla çalışma saatleri, ücretlerde farklılığa neden olmaktadır. Türkiye'de çalışma saatleri 4857 sayılı İş kanununda da belirtildiği gibi haftalık 45 saat üzerinden hesaplanmaktadır. 45 saati aşan çalışmalarda mesai ücretinin ödenmesi gerekmektedir. Fakat haftalık 45 saatten fazla çalışıp ücrete yansımadığı durumlar da mevcuttur. Bu durumun işverenin inisiyatifine bırakılması ücret farklılıklarına yol açmaktadır. Diğer taraftan, yapılan işin niteliği o sektördeki ücretleri etkilemektedir. Eğer bir iş yüksek nitelik gerektiriyorsa ve az sayıda işçi bu niteliğe sahip ise alınan ücretler buna bağlı olarak yüksek olmaktadır. İşi öğrenme süreci ne kadar zahmetli ise ücretler bununla doğru orantılı olarak artmaktadır. (Bozkurt ve Bozkurt, 2008: 5) Emek arzının niteliği olduğu kadar niceliği de ücretleri etkileyen faktörler arasındadır. Gerek makro gerekse mikro ekonomik bir niteliğe sahip olan emek arzının niceliği bir sektördeki, bölgedeki hatta bir ülkedeki genel ücret haddi üzerinde etkili olmaktadır. Bir işte çalışmak isteyen kişi sayısının (emek arzının), piyasadaki açık işlerden (emek talebinden) fazla olması ücretlerin düşük olmasına neden olacaktır (Ataman, 1998: 65). A.Smith (1776)'in Ulusların Üstünlüğü eserinde de belirttiği üzere ücretlerin farklı olmasının nedenleri arasında istihdamın sabitliği de etkili olmaktadır. İşin kısa ya da uzun süreli olması istihdamın sabitliği ile ilgilidir. A. Smith'e göre, cari piyasa koşullarında üretimi veya talebi mevsimlik olan veya işten çıkarmaların yoğun olduğu düzensiz veya kısa süreli işlerde çalışanların ücretleri, çalışamadıkları dönemde alamadıkları ücretlerini dengeleyebilmek için, daha düzenli işlerde istihdam edilenlerin ücretlerinden daha yüksek olmalı ve bu durum ücret farkl1lığına neden olacaktır. Diğer taraftan piyasa içinde yapılması mecburi bazı işler işin süresi veya işin niteliği ile ilgili olarak insan bedeninin bütünlüğünü tehdit edebilmekte ya da insan doğasına aykırı olan bazı tehlikeler ve riskler içerebilmekte, bazı işler ise daha düşük prestijli olabilmektedir. Bu durumdaki firmalar gereken nitelikteki işgücü arzını kendi çekebilmek için diğer firmalar göre daha fazla ücret ödeyecektir. Böylece ilk olarak A. Smith tarafindan ortaya atılan “telafi edici ücret farklılıkları” ile işin ve işyerinin kötü çalışma koşulları ya da düşük statüsü telafi edilmiş olmaktadır (Lordoğlu\&Özkaplan, 2007: 263). Bu bağlamda kariyer imkânı ve mesleki prestij işçilerin ücret düzeyini belirleyen ve ücret düzeylerinde farklılığa neden olan faktörler arasında yer almaktadır. Prestij ve statü kalıpları toplumsal değer yargıları ve zaman içinde değişen bir olgu olmasına karşın ücret düzeyini arttırmaktadır. İşyerinde kariyer imkânı olan işçilerin aldıkları ücretin kariyer imkânı olmayan işlerde çalışanlara göre yüksek olduğu görülmektedir. Doeringer ve Piore'nin (1971) tabakalaşma kuramına göre birincil piyasaların diğer adının kariyer piyasası olmasının sebebi de budur. Kariyer piyasasında işçiler, ikincil piyasada çalışan işçiler ile aynı işi yaptıkları halde daha yüksek ücret almakta ve kariyer imkânı elde etmektedirler. Bununla ilgili olarak firma büyüklüğü (ölçek) ücretleri etkileyen faktörler arasında yer almaktadır. Firmaların büyülüğü arttıkça ücretler artmaktadır. Büyük firmalarda yüksek nitelikli emeğin istihdam edilmesi, makine teçhizata olan yatırımlar, uzmanlaşma ve işbölümü verimliliği arttırmakta dolayısıyla ücretlerin artmasına neden olmaktadır. Ücret farklı1ıkları konusunda belirleyici bir diğer faktör sendikaların varlığıdır. Aynı faaliyet alanında olup sendikal hak ve kazanımlarla daha yüksek ücret ile çalışan işçiler olmakta ve bu durum ücretler arasında farklılı̆̆a neden olmaktadır. 
Fakat işgücü piyasalarının yerellikten çıkması ve çalışma biçimlerinin esnekleşmesi ile birlikte sendikal kazanımlar azalmıştır. İşveren ücret ve özlük hakları konusundaki pazarlığı işçi ile bizzat yaparak daha karlı çıkarımlar elde etmiş ve sendika faktörünü işçiyi ücret ve diğer hakları ile tehdit ederek azaltmıştır. Bu durum sendikaların yetersizliği olarak ifade edilse de burada önemli olan işçiler arasında yarattığı ücret eşitsizliğidir (Selamoğlu ve Urhan, 2008: 196). Büyük firmalarda ücretlerin yüksek olması kısmen bu firmalarda sendikalaşmanın yüksek olmasından kaynaklanmaktadır.

\section{3. Ücret Yapısı İle İlgili Faktörler}

Çalışanların ücretten memnun olması; ücretin piyasa düzeyinde olmasına, işçinin zam alma sıklığına, ücretin düzenli ödenip ödenmemesine, sosyal yardımlara, teşvik ve primlere bağlıdır. İşçinin zam alma sıklığı ve ücretin düzenli ödenmesi işçinin işyerine bağlılığını ve motivasyonunu arttıran faktörler arasındadır. Alınan ücretlerin piyasa düzeyinin altında ya da üstünde olması ücret memnuniyetini etkileyen en önemli faktörlerden biridir. Ücreti belirleyenler sadece piyasa düzeyindeki ücret, zam alma sıklığı veya düzenli ödenmesi ile ilgili değildir. Ücretin yapısı iş analizleri ve tanımları ile de ilgilidir. Aslında ücretin yapısı, bir işletme içindeki bir işin ücretinin diğerler işlere göre ne kadar farklı olacağını belirler. Bunun temel amacı tüm çalışanların yaptığı işe ve performansa göre hak ettiği ücreti dengeli bir şekilde almasıdır (Benligiray, 2003: 68). Bir organizasyon içindeki işlerin birbirlerine göre değerlerini, nesnel ölçütlere dayanarak, belirleme işlemi olan iş değerlendirmesi, ücret sisteminin oluşturulmasında önemli bir yere sahip olan iş analizleri ve iş tanımlarının yapılmasına ihtiyaç duymaktadır. Ancak sağlıklı iş tanımlarının yapılması sonrasında işlerin göreli değerleri bulunabilecek ve işler değerlendikten sonra da performansa göre ücretler belirlenecektir. Ücretin adil olarak belirlenmesi de iş değerlendirmesinin ilkelerinden biri olan eşit işe eşit ücret ilkesine göre olması önem arz etmektedir. Bir işin önceden belirlenmiş sabit bir ücretinin olması ve o iş üstünde çalışan birinin o ücreti alması adaletli ve dengeli bir ücret yapısı oluşturma amacına hizmet eder. İş değerlendirmesi esas olarak adil bir ücret sistemi sağlayarak ücretler arasındaki farklılıkları azaltır ve işlerin önem ve güçlüklerine göre ücretlendirilmelerini sağlamaktadır (Işs̆ğıçok, 2011: 192-194). İş değerlendirmesine uygun bir ücretlendirmenin yapılmadığı ya da işin önem ve zorluk derecesine göre ücret farklarının önemini kaybettiği işletmelerde işçinin başka pozisyonlara geçmek istemesi gibi olumsuz yönelimler yaygın olarak yaşanmaktadır.

\section{TABAKALI İ̧GÜCÜ PIYYASASI VE TABAKALAŞMA TEORİSI}

İşgücü piyasası genel olarak tabakalı bir yapı arz etmektedir. Gelir dağılımı, işsizlik, ücretlerin belirlenmesi, cinsiyete dayalı ücret eşitsizliği ve ayrımcılık sorunlarının kaynağında işgücü piyasasındaki tabakalaşma (bölümlenme, katmanlaşma) etkili olmaktadır. Tabakalı işgücü piyasası teorisine iş̧̧iler ve işlerin evrensel bir piyasa mekanizması ile sorunsuz bir şekilde eşleşemediğini öne sürerek Neo-Klasik teoriye ve beşeri sermaye teorisini eleştirmiştir (Dickens ve Lang, 1992; Bauder, 2001). Tabakalı işgücü piyasası teorisine Kurumcu iktisatçıların görüşleri hakim olurken, Marksist ve 
Neo-Marksist iktisatçıların işgücü piyasasında ayrımcılık konusunda yapmış olduğu analizler de tabakalı işgücü piyasası teorilerine dayanmaktadır (Lordoğlu\&Özkaplan, 2007:102). Kurumcu İktisatçılar, Neo-Klasik teorilerinin aksine bireylerin kendi rasyonel, özgür tercihlerine göre iş olanakları arasında seçim yapamadıklarını, işgücü piyasalarını esnek olmadığını, tekelci firmalar ve kurumsal düzenlemeler nedeniyle bazı çalışanların kendi istekleri dışında, daha düşük şartlarla donatılmış, ikincil piyasalarda çalışmak zorunda kalacağını vurgulamaktadır.

Ekonomideki ve işgücü piyasasındaki tabakalaşma sırasıyla ikili ekonomi teorisi (Averitt, 1968) ve ikili işgücü piyasası teorisinden (Doeringer\&Piore, 1971) türetilmiştir. $\mathrm{Bu}$ bağlamda tabakalaşmanın en önemli konusu “İkili İşgücü Piyasaları" yaklaşımıdır. İkili işgücü piyasaları teoremi eski Kurumcu iktisatçıların literatüre katkısı olarak kabul edilmekte ve iki farklı ayrım çerçevesinde ele alınmaktadır. İlk olarak, işgücü piyasaları "içsel (firma içi)" ve "dışsal (firmalar arası)" olarak ayrılmaktadır. Buna göre, içsel işgücü piyasası piyasasının talep yönünü yani işveren davranışları üzerinde dururken birincil işgücü piyasası içinde bulunan büyük firmaların ödeme sistemi ve işler için içsel işgücü piyasası ile bir yapı oluşturulduğu belirtilmektedir. İçsel işgücü piyasası işçilere ve güvenli bir ortam düzenli, uzun dönemli ve yüksek ücretli bir iş, işten çıkarma ve tazminat ile ilgili kurallar, iş güvenliği, işe alma ve yükseltme ilişkin kurallar ve hizmet içi eğitim sağlamaktadır (Uyanık, 1999). Kısaca firmanın içindeki işgücü piyasası olarak da tanımlanan içsel işgücü piyasası dışsal piyasadaki rekabet güçlerinden bağımsız işlemektedir (Ataman, 1998:7). Diğer taraftan firmaların alt kademe işler için işlendireceği işgücünü dışardan sağladığı, ücretlerin firmanın yönetsel kuralları ve yöntemleri tarafından belirlenmediği piyasa ise dışsal işgücü piyasası olarak tanımlanmaktadır. Firmalar genellikle alt kademe pozisyonlar için dışsal piyasadan yeni işgücü almayı tercih ederken, daha üst düzey ve önemli pozisyonlar için içsel piyasadan (firma içinden) personel kaydırma yoluna gitmektedir (Lordoğlu ve Özkaplan, 2007:105).

İkinci ayrımda ise, işgücü piyasasında "Birincil” ve “İkincil” piyasa olmak üzere ikili bir yapının varlığı ortaya konmaktadır. Doeringer ve Pioere (1971) tarafından birincil iş piyasasındaki işler "iyi işler", ikincil iş piyasasındaki işler ise "kötü işler" olarak ayrılmakta ve işgücü piyasalarındaki ücret farklılıklarının nedeni bu ikili yapıdan kaynaklanmaktadır. Her bir piyasanın kendine özgü bir ücret stratejisi ve istihdam politikası vardır. Bu ayrıma göre, birincil piyasalardaki işler yüksek ücret, iyi çalışma koşulları, istikrarlı istihdam, terfi imkânı, eşitlik ve buna bağlı olarak iş kuralları şeklinde sıralanırken, ikincil piyasalardaki işler düşük ücret, düşük statü, sınırlı sosyal haklar, sağlıksız çalışma koşulları, yüksek işgücü devri, sınırlı terfi imkânı, keyfi ve istikrarsız denetimler şeklinde siralanmakta (Hudson, 2007: 288) ve ücret farkl1lklarının temel sebeplerini bunlar oluşturmaktadır (McNabb,1987:259). Diğer taraftan birincil sektördeki iyi işler genellikle sermaye yoğun üretim teknolojilerinin kullanıldığı endüstrilerden oluşmaktadır. Burada düzenli üretim talebi ve yüksek üretim hacminin ve sendikalaşmanın olduğu firmalar bulunmaktadır. Bu piyasada bulunan işgücünün eğitim düzeyi yüksektir. Burada çalışan vasıflı işgücü kafa ve kol emeğini birleştirme 
kapasitesine sahip, uzman işgücüdür ve bu işgücünü çalıştıkları firmaları ve sendikaları ile güçlü bağları mevcuttur (Levitan, Mangum, Marshall ,1976:12). İkincil işler ise daha çok birincil sektördeki firmalara bağımlı olarak fason üretimde bulunan, emek yoğun rekabetçi endüstrilerde bulunmaktadır ki piyasada üretim talebi düzensiz ve azalan bir trende sahiptir (McNabb,1987:260). İkincil işgücü piyasasında sendikalaşma oranının düşük olduğu, daha çok küçük ve orta ölçekte işletmelerin yer aldığı, işgücü değerlendirmelerinde cinsiyet, ırk, renk gibi özelliklerin ön plana çıktı̆̆ı, eğitim ve yetişme gibi faktörlerin ağılıklı olarak etkisinin bulunmadığı görülmektedir (Levitan, Mangum, Marshall, 1976:12). Çalışanların konumları, motivasyonları, iş alışkanlıkları birincil veya ikincil piyasalarda birbirlerini etkileyen faktörler olmaktadır. Yani birincil piyasalarda çalışanlar birincil piyasaların özelliklerine uygun çalışırken, ikincil piyasalarda çalışanlar birincil piyasaların özelliklerine sahip olsalar bile çalıştıkları piyasanın özelliklerine uygun olarak çalışmaktadırlar (Cain, 1975: 19).

\section{4. ÜCRET FARKLILIĞI ÜZERINNE YAPILMIŞ ÇALIŞMALAR}

Bu bölümde, Türkiye'de tabakalı işgücü piyasası ve ücret farklılıklarına ilişkin yapılmış çalışmalar ve bulguları kısaca aşağıdaki gibi özetlenmiştir. Ercan ve Tunalı (1998) birincil sektörde büyük firmalar, ikincil sektörde ise küçük firmaları ele alarak tabakalı yapıyı incelemiştir. Firma büyüklüğü yaş, cinsiyet, eğitim, kıdem, kır-kent, bölge işin sürekliliği gibi çeşitli değişkenleri alındığ1 çalışma sonucunda, büyük firmalardaki gelir seviyesinin küçük firmalara göre aylık ücretlerle \%27, yıllık ücretlere göre ise \%35 daha fazla olduğunu gözlemlemiş̧tir. Levent, Taştı ve Sezer (2004) 2003 yılı hane halkı işgücü anketlerini kullanarak piyasadaki tabakalı yapının ücret farklılıklarını analiz etmişlerdir. Sonuç olarak kayıtlı sektörde ücretlerin belirlenmesinde kıdem ve eğitim düzeyi öne çıkarken, kayıt dışı sektörde ise cinsiyet ve yarı zamanlı çalışma etkili olmuştur. Erdal Aydın (2009) formel ve enformel sektörlerdeki ücret farklılıklarını tabakalı yapı içinde incelemiştir. TÜíK'in 19882006 yılı hane halkı işgücü anketi mikro verilerinden faydalanılan çalışmanın sonuçlarına göre, incelenen dönemde ücret seviyeleri arasındaki fark artmıştır ve tabakalı yapının en önemli sebebi olarak açıklanamayan ücret farklılıkları öne sürülmüştür. Kumaş, Çağlar ve Karaalp (2014)'in TÜíK 2011 mikro veri setinden faydalanarak firma büyüklüklerine göre tabakalı işgücü piyasasının varlığı araştırdığı çalışmasında işler "iyi işler” ve "kötü işler” ve ücret yapısına göre ele alınmış, Türkiye' de cinsiyet, yaş, eğitim, medeni durum, ana faaliyet alanı, sosyal statü ve mesleklere bağlı olarak tabakalı bir yapı tespit edilmiştir.

\section{5. İNŞAAT SEKTÖRÜNE GENEL BİR BAKIŞ}

İnşaat sektörü, gerek toplam yatırımların milli gelir içindeki payı, gerekse yaratılan işgücü olanaklarının boyutu itibarıyla Türkiye ekonomisinin öne çıkan sektörlerinden biridir. Barajlar, enerji üretim tesisleri, yollar, havaalanları, kentsel mekânlar, fabrikalar, hastaneler ve diğer tüm mekânların yapımı nedeniyle Türkiye ekonomisinin önemli sektörlerinden birini inşaat sektörü oluşturmaktadır. 


\section{ŞEKİL 1. TÜRKIYYE GSYH VE INNŞAAT SEKTÖRÜNDE BÜYÜME}

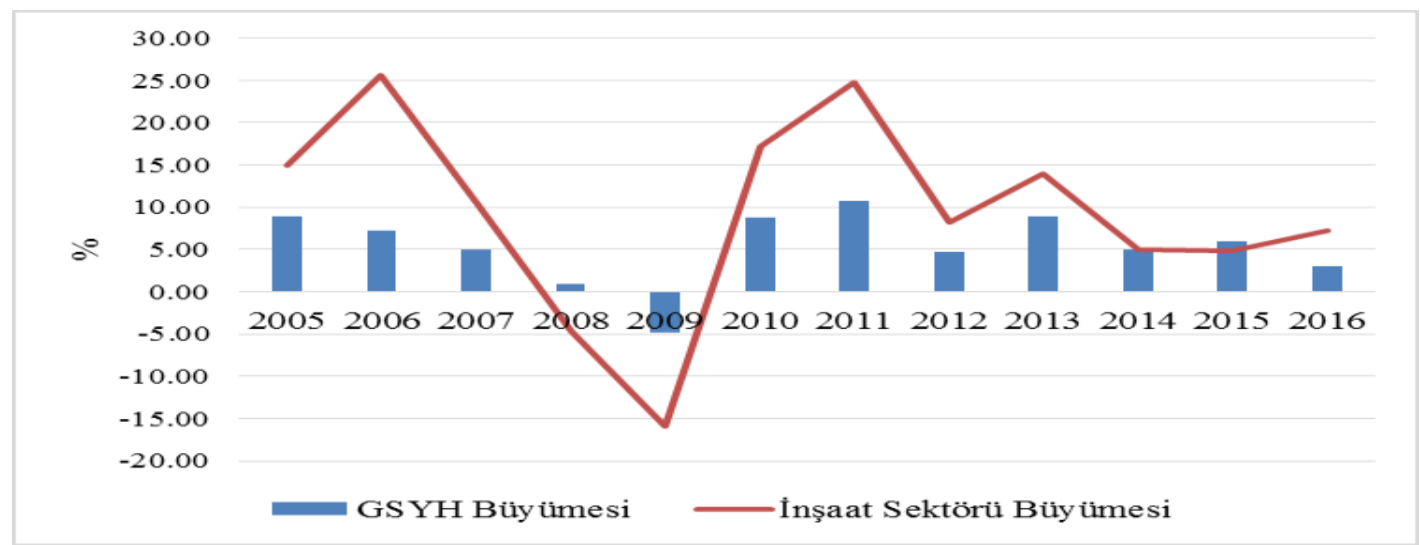

Kaynak: TÜİK (2017a), Dönemsel Gayrisafi Yurtiçi Hasıla (2009=100).

Şekil 1'de inşaat sektörünün gelişim hızının Türkiye ekonomisinin gelişim hızı ile paralellik gösterdiği gözlenmektedir. Sektörün ekonomik büyümeye duyarlılığı yüksek düzeydedir. Genel olarak inşaat sektörü ekonominin büyüme dönemlerinde GSYİH'den daha hızlı artarken, daralma dönemlerinde ise GSYİH'den daha hızlı düşüşler sergilemektedir. Ülke ekonomisinde artan inşaat yatırımları nedeniyle inşaat sektörüne dayalı ekonomik büyüme modelinin uygulandığına yönelik yapılan eleştirilerle birlikte altyapı ve konut ihtiyaçlarına yönelik artan talepler sektörün büyümesinde de etkili olmuştur. 2015 yılında pozitif bir büyüme gözlenen sektörde, 2016 y1lında Türkiye ekonomisinin daralmasına karşına büyüme devam ederek 2016 yılında \%7.2'ye ulaşmıştır. Sektöre girdi sağlayan ve faaliyetlerini bu sektördeki gelişmelere bağlı olarak devam ettiren diğer sektörlerin katkısı da dikkate alındığında inşaat sektörünün milli gelir içindeki payı da yıllar itibariyle artmaktadır. 2016 y1lı için inşaat sektörünü oluşturan faaliyetlerin toplam katma değeri 119 milyar 602 milyon TL olmuş buna göre inşaat sektörünün GSYİH içindeki doğrudan pay1 \%8.8'e yükselirken, bağl1 sektörlerle birlikte sektörün GSMH içerisindeki pay1 \%30 düzeyinde olmuştur (INTES, 2017:2). Diğer taraftan inşaat sektörün yarattığı en önemli dışsallıklardan bir tanesini istihdam yaratmasıdır. Buna göre Şekil 2'de 2005-2016 yılları arasında toplam istihdam içinde inşaat sektörünün payının arttı̆̆g görülmektedir. 


\section{ŞEKİL 2. TOPLAM İSTIHDAM VE INNŞAAT SEKTÖRÜNÜN PAYI}

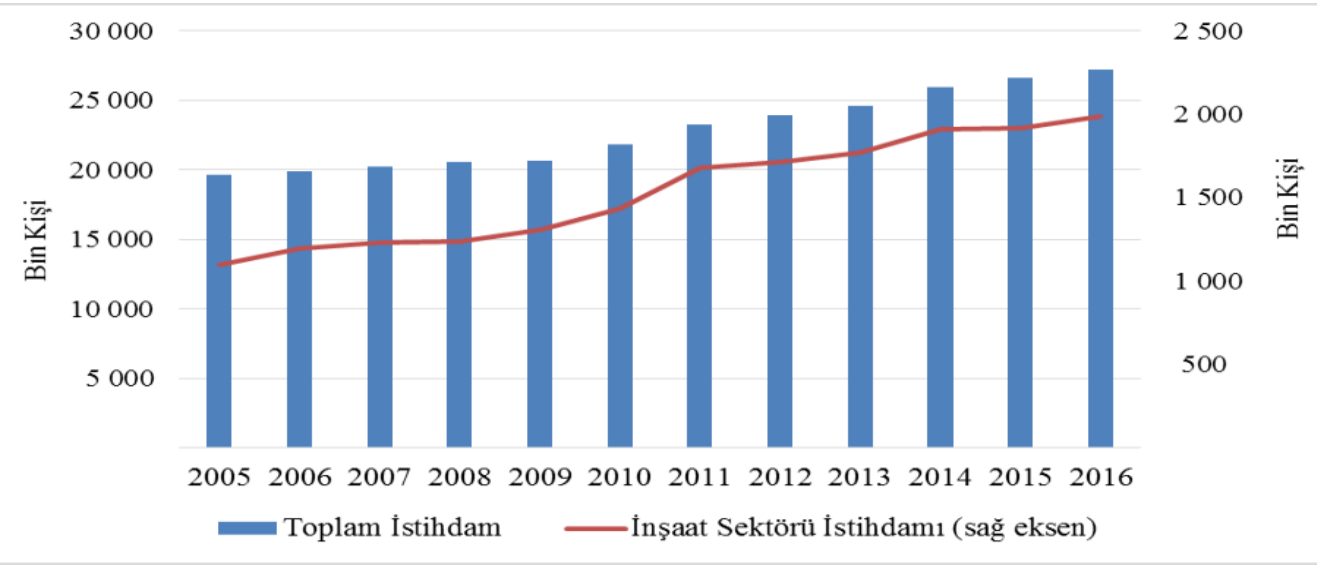

Kaynak: TÜİK (2017b), İşgücü İstatistikleri

2005 yılında inşaat sektörünün toplam istihdam içindeki inşaat sektörünün payı \%5.6 iken 2016 yılında toplam istihdamın \%7.3'e yükselmiştir (TÜIK 2017b). Buna göre 2016 yllında toplam istihdam 27 milyon 205 bin kişi iken, inşaat sektöründe 1 milyon 987 bin kişi istihdam edilmektedir. İnşaat sektörü bünyesinde nitelikli ve niteliksiz meslek gruplarını kapsayan geniş bir yelpaze içermektedir. Hakim üretim tarzı olarak emek yoğun niteliğini korumaya devam eden inşaat sektöründe eğitim düzeyi oldukça düşüktür. Niteliksiz işgücü istihdamı, sektörün en temel sorunları arasında yer almaktadır. Mesleki eğitim talebinin düşük olduğu sektörde eğitim ve istihdam ilişkisi zayıftır (İnşaat Sektörü-Ulusal İstihdam Stratejisi, 2016:10). 2016 yılı verilerine göre, sektörün yaklaşık \%70'si lise altı eğitim düzeyine sahip iken, \%17'si genel lise ve lise dengi mesleki okul mezunu olup sadece \%10'u yükseköğretim mezunlarından oluşmaktadır (INTES, 2017:10). Eğitim düzeyi daha düşük olan sektörlerde emeğin mobilitesi yüksek olması ve özellikle inşaat sektörünün kırsal kesimden kentlere gelen vasıfsız, eğitim düzeyi düşük işgücünün istihdam edilmesine imkan sağlaması nedeniyle kalıcı bir iş bulmak isteyenler geçici olarak inşaat sektöründe istihdam imkanı bulabilmektedir (İnşaat Sektörü-Ulusal İstihdam Stratejisi, 2016:5). 2016 yılı verilerine göre, meslek grupları açısından istihdam edilenlerin \%50'si içinde inşaat sektörünü de içinde barındıran sanatkarlar ve ilgili işlerde çalışanları kapsarken, yaklaşık \%20'si nitelik gerektirmeyen işlerde çalışanları kapsamaktadır (INTES, 2017:9-10). Farklı eğitim düzeyine sahip farklı meslek gruplarını istihdam edildiği inşaat sektörü içinde işgücü piyasasındaki tabakalaşma gözlenmektedir. Şöyle ki, sektör içinde çok sayıda firmanın oluşu çeşitli istihdam olanakları sağlamakta, fakat sektör içinde gözlenen birincil ve ikincil piyasalar etkisi nedeniyle başta ücret farklılı̆̆ düşüklüğü, kariyer beklentisinin olmaması, istihdamın düzenli olmaması ve kötü çalışma koşulları gibi sorunlar yaygın olarak görülmektedir. 


\section{ANKARA İLİ İNŞAAT SEKTÖRÜ ÜZERİNE BİR ALAN ARAŞTIRMASI}

Bu bölümde Ankara ili inşaat sektörü üzerine yapılan alan araştırmasının amacı, önemi, kapsamı ve kısıtları açıklanmıştır. Ayrıca, araştırmada kullanılan analiz ve veri toplama yöntemine ilişsin bilgiler ve son olarak araştırma bulgularına yer verilmiştir.

\subsection{Araştırmanın Amacı ve Önemi}

Bu çalışmada, inşaat sektöründe istihdam edilen (teknik personel ve işçiler) arasındaki ücret farklılıklarının tespiti ve ücret farklılıklarına neden olan faktörlerin ortaya konması amaçlanmıştır. $\mathrm{Bu}$ kapsamda inşaat sektöründe çalışan gerek beyaz gerekse mavi yakalıların aynı işi yaptıkları halde farklı firmalarda çalıştıkları için maruz kaldıkları ücret farklılıkları tabakalı işgücü piyasası çerçevesinde ele alınmıştır.

\subsection{Araştırmanın Yöntemi ve Verilerin Toplanması}

Makalenin konusunu oluşturan alan araştırması Ankara ili kapsamında genel faaliyet alanı inşaat sektörü olan 4 firma üzerinde yapılmıştır. Bu firmalardan ikisi holding bünyesinde faaliyet gösteren büyük (kurumsal) firmalar iken diğer ikisi ise alt işveren (taşeron) firmasıdır. Araştırma kapsamında 36 erkek ve 5 kadın olmak üzere toplam 41 kişi ile yüz yüze görüşülmüştür. Kurumsal firmalarda çalışan 12 işçi, 5 tekniker ve 15 mühendis, taşeron firmalarda çalışan 6 işçi ve 3 mühendise ücret farklılıklarını ölçmeye yönelik 16 soru yöneltilerek yarı yapılandırılmış derinlemesine mülakat tekniği uygulanmıştır. Gerek beyaz yakalı gerekse mavi yakalı inşaat sektörü çalışanlarının seçiminde rastgele örnekleme yöntemi kullanılmıştır. Diğer taraftan, birçok araştırmada olduğu gibi bu araştırmada da ana kütlenin büyüklüğü ve zaman kısıtı nedeniyle araştırma sınırlı sayıdaki görüşmeci ile gerçekleştirilmiştir. Araştırma kapsamında görüşülen kişilerin çalıştığı firmalar için analiz kısmında taşeron firmalar $\mathrm{T} 1$ ve $\mathrm{T} 2$ ve kurumsal firmalar $\mathrm{K} 1$ ve $\mathrm{K} 2$ olarak adlandırılmıştır. Kat1lımcılar ise; mühendisler M1, M2...vb., teknikerler TEK1, TEK2...vv. işçiler ise İ1, İ2,..vb şekilde adlandırılmıştır.

\subsection{Araştırmanın Bulguları}

Alan araştırması kapsamında görüşülen katılımcılara ilişkin yaş, medeni durum, meslek ve eğitim gibi demografik bulgular şu şekildedir: Araştırmaya katılan 41 kişinin 36'sı erkek, 5'i kadındır. Araştırma kapsamında beyaz yakalı olarak tekniker ve mühendislerle, mavi yakalı olarak ise sadece işçilerle görüşülmüştür. Görüşme yapılan firmalarda farklı meslek gruplarındaki (çaycı, temizlik personeli vb.) çalışanlar görüşmeye dahil edilmemiştir. Buna göre; toplamda 23 beyaz yakalı (mühendis ve teknik personel) ve 18 mavi yakalı (işçi) personel ile görüşülmüştür. Görüşmecilerin ortalama yaşları ise 25-51 arasında değişmektedir. Görüşülen kadın mühendislerin hepsi bekar olup, 3 işçi dışındaki erkeklerin hepsi evlidir. 18 mühendisin hepsinin üniversite mezunu iken, 10 mühendis yüksek lisans mezunudur. İşçilerin ise, 5'i ilkokul, 6'sı ise ortaokul mezunu iken, 7 işçi lise terktir. 


\subsection{1. İşgücünün Özelliklerine İlişkin Bulgular}

Ücret farklılığına neden olan faktörlerin başında işgücünün farklı niteliklere sahip olmasından kaynaklanan beşeri sermaye farklılıkları yer almaktadır. Alan araştırmasından elde edilen bulgulara göre inşaat sektöründeki işgücünün özelliklerinden kaynaklı olarak ücret farklılı̆̆ına neden olan faktörler sektördeki tabakalı işgücü piyasası özelliklerini de ortaya koymaktadır. Ücret farklılığına neden olan faktörler arasında eğitim ve mesleki tecrübe (ve dolayısıyla yaş) öne çıkmaktadır. Diğer taraftan birincil piyasada çalışan mühendislerin ve işçilerin eğitim düzeylerinin, yaşlarının ve mesleki tecrübelerinin daha yüksek olduğu tespit edilmiştir. San (2012) çalışmasında da benzer sonuçlar elde edilmiştir. Buna göre, büyük firmalarda çalışanların ortalama olarak yaşı, tecrübesi, eğitim düzeyi, kayıtlı çalışma oranı ve evlilik düzeyinin küçük firmalarda çalışanlara göre daha yüksek olduğu tespit edilmiştir. Aydın, Hisarcıklılar ve İlkkaracan'ın (2010) Türkiye'deki serbest piyasalarda kayıtdışı işgücü piyasasının tabakalaşması üzerine yaptıkları çalışmada ücret farklılıklarını açıklanabilen faktörler (eğitim, mesleki deneyim ve işteki çalışma süresi) ve açıklanamayan faktörler (mesleki ve bölgesel farklılıklar) olmak üzere iki temel esasa bağlamış ve ücret farklılıklarının eğitim ve kıdeme bağlı olarak ortaya çıktığı tespit etmişlerdir.

Görüşme yapılan kurumsal ve taşeron firmalarda çalışan mühendislerin tümü üniversite mezunu olup, 10 kişi ise yüksek lisans mezunudur. Yüksek lisans mezunu olan mühendislerin hepsinin kurumsal firmalarda çalışması eğitim seviyesi daha yüksek olan mühendislerin nitelikli işgücü olarak birincil piyasada yer aldığı göstermektedir. Kurumsal firmalarda çalışan işçilerin eğitim düzeyi ise nisbi olarak taşeron firmalarda çalışan işçilerden daha yüksektir. Kurumsal firmalarda çalışan işçilerin çoğunluğu ortaokul mezunu (6 kişi) ve lise terk (5 kişi) iken 1 kişi ilkokul mezunudur. Taşeron firmalarda çalışan işçilerin ise çoğunluğu ilkokul mezunu (4 kişi) olup 2 işçi lise terktir.

Yaş faktörü açısından ise kurumsal firmalarda çalışan gerek işçi gerekse mühendislerin yaş ortalamalarının nisbi olarak daha yüksek olduğu tespit edilmiştir. Taşeron firmalarda görüşülen mühendislerin yaşları 28-34 iken, kurumsal firmalarda çalışan mühendisler 27- 51 yaş aralığındadır. Kurumsal firmalarda çalışan 12 işçinin yaşları 25-46 arasında değişmekte iken, taşeron firmalarda çalışan işçilerin yaşları 21- 45 arasında değişmektedir. Taşeron firmalarda çalışan işçiler arasında yaşa bağlı bir ücret farklılığa rastlanmazken kurumsal firmalarda ücretlerin yaşa bağlı değiştiği görülmüştür. Bu durum mesleki tecrübe ile de ilişkilidir. Kurumsal firmalarda, tecrübeli işçiler ve kıdemsiz genç işçiler arasında belirgin bir ücret farklılığı görülmüştür. Görüşme yapılan her iki kurumsal firmadaki ustabaşı ve ekip sorumlusu sıfatına sahip mavi yakalıların tümünün 45 yaşının üstünde olduğu ve geri kalan mavi yakalılardan daha yüksek ücret aldıkları saptanmıştır. Buna karşın taşeron firmalarda çalışan orta yaşlı işçilerin genç işçilere göre daha fazla tecrübeye sahip olmasına rağmen aynı ücreti aldığı belirtilmiştir. Dolayısıyla kurumsal firmalarda işçiler arasındaki ücret farklılıklarında yaş ve mesleki tecrübe etkili olmakta iken taşeron firmalarda çalışan işçiler arasında yaş ilerledikçe ücretlerde belirgin bir farklılık görülmemektedir. Kumaş, Atalay ve Karaalp'in (2014) 
2013 yılı mikro veri seti ile yapmış olduğu çalışmada ikincil sektörde çalışanların yaş ortalamasının genç olduğu ve birincil sektördekilerden daha düşük ücret aldıkları tespit edilmiştir (Kumaş vd., 2014:369). Bununla birlikte, tabakalı işgücü piyasasının bir özelliği olarak birincil ve ikincil piyasada yeni işe başlayan tecrübesiz bir mühendisin başlangıç ücretleri arasında da farklılık olduğu tespit edilmiştir. Bu farklılığı T1 firmasında çalışan mühendis (M1) şu şekilde ifade etmiştir: "Bizim çalıştı̆̆ımız firmada ben ilk işe başladığımda aldı̆̆ım ücret ustabaşının aldĭ̆ı ücretten biraz daha yüksekti. Yani bir ustabaşı 1700TL allyorsa yeni başlayan bir mühendis de 2000-2500TLl arasinda çalışıyor. Kurumsal firmalardan işçiler ve mühendislerin ücretleri arasındaki ayrım oldukça belirgindir. Fakat taşeronda çalışan yeni mühendislerin ücretleri öyle değil.",

İlk olarak işgücü piyasasının belirli bir tabakasında düşük ücretle işe başlayan bir kişinin aynı niteliklere sahip olmasına rağmen diğer meslektaşlarına göre ilerleyen yıllarda da daha düşük bir ücret düzeyi ile devam etmesi, işgücü piyasasının tabakalı yapısını işaret etmektedir.

Cinsiyet açısından ele alındığında ise, yaygın olarak erkeklerin tercih ve istihdam edildiği inşaat sektöründe görüşme yapılan firmalarda çoğunlukla erkek mühendislerin istihdam edildiği görülmüştür. Görüşülen 18 mühendislerin yalnızca 5 tanesi kadındır. Dedeoğlu (2009)'nun da belirttiği gibi Türkiye'de işe almada cinsiyete dayalı ayrımcılık çok yaygın olarak karşılaşılmaktadır. Toplumsal cinsiyet rolleri ve işbölümüne göre mühendislik gibi teknik konuların "erkek işi” olup erkeklerin çalışması olağan görülürken, kadınların teknik işlerden anlamayacağına yönelik algının oluşmaktadır. Diğer taraftan, görüşme yapılan kadınların hepsinin kurumsal firmada mühendis olarak çalışmaktadır. $\mathrm{Bu}$ durum işgücü piyasalarında cinsiyete dayalı tabakalaşmadan farklı olarak kadın mühendislerin kariyer firsatları, çalışma koşulları ve ücretlerin daha iyi olduğu güvenceli ve düzenli birincil piyasada istihdam edildiği görülmektedir. Diğer taraftan medeni durumun gerek kurumsal gerekse taşeron firmada çalışanların ücretlerini etkilemediği ifade edilmiştir. Kadın mühendislerin hepsi bekar olup, 3 erkek işçi hariç geri kalan tüm işçiler ve erkek mühendisler evlidir.

\subsection{2. İşin Niteliğine İlişkin Bulgular}

Ücret farklılığa neden olan işin niteliğine özgü faktörlerin ortaya konması amacıyla görüşmecilere çalışma saatleri, hafta sonu çalışıp çalışmadıkları, kariyer imkânının olup olmadığı ve herhangi bir sendikaya üye olup olmadıklarına ilişkin sorular sorulmuştur. İşin niteliğine ilişkin bulgular açısından kurumsal firmaların aksine taşeron firmalarda çalışan mühendislerin $\mathrm{k}$ hafta sonları çalışması ve kariyer olanaklarını yetersiz görmesi inşaat sektöründeki tabakalı işgücü piyasasının varlığını göstermektedir. Gerek birincil gerekse ikincil piyasadaki firmalarda çalışan mühendis, tekniker ve işçilerin hiçbirinin sendikaya üye olmadığı belirtilirken, işçilerin sendikaya üye olmak istedikleri ifade edilmiştir.

Araştırma kapsamındaki gerek taşeron gerekse kurumsal firmalarda çalışan 18 işçinin tamamı hafta sonu çalıştıklarını belirtmiştir. Kurumsal firmalarda çalışan işçiler hafta sonları da dahil 07.30- 
18.00 saatleri arasında çalışırken, taşeron firmalarda çalışan işçiler 08.00-18.00 saatleri arasında çalışmaktadır. Diğer taraftan kurumsal firmalarda çalışan teknikerler ve taşeron firmalarda çalışan 3 mühendis de hafta sonu çalışıldıklarını beyan etmiştir. Fakat her iki kurumsal firmada çalışan mühendisler sadece hafta içi 09.00-18.00 saatleri arasında çalıştıklarını bildirmiştir. Buna göre birincil piyasada çalışan mühendislerin hafta sonu çalışmadığı tespit edilmiştir.

Sendikaya üye olup olmama sorusuna verilen cevapların tümü olumsuzdur. Gerek kurumsal gerekse taşeron firmalarda çalışan mavi ve beyaz yakalıların hiçbiri herhangi bir sendikaya üye değildir. Hatta K1 firmasında çalışan bir yüksek mühendis (M2) sendikalı olmaya ilişkin görüşünü şöyle aktarmıştır: "Hayır sendikalı değilim. Bildiğim kadarıyla bu şirkette çalışanların hiçbiri sendikalı değil. Zaten bence buna ihtiyacımı da yok. Ücretlerimiz piyasa düzeyinin üstünde ve şirketimiz bütün sosyal haklarımızı karşıllyor”. Bu soruya T2 firmasında mühendis (M4) şu cevab1 vermiştir: "Sendikalı değilim. Hiçbir bağımız olmadı sendika ile. Çünkü patronumuz sendika karşıtı biri. Açıkçası haklarımızı savunan bir kurum olsa iyi olurdu. Ama o zaman da işimize son verilirdi.",

İşçiler açısından bakıldığında durum biraz daha farklıdır. Görüşme yapılan 18 işçinin hiçbiri sendikalı değildir, fakat sendikaya sıcak bakmaktadır. T1 firmasında çalışan işçi (İ1) sendikalı olma konusunda şunları söylemiştir: “ Hiçbirimiz sendikalı değiliz. Sendikalı olmak isterdim ama patron istemiyor". K2 firmasında çalı̧̧an işçi (İ3) ise bu soruya "Maaşlarımız düzenli ödeniyor. Sigortamız da düzenli ama yine de sendikalı olmak isterdim. " cevabını vermiştir.

Görüşmecilerin vermiş olduğu cevaplar, esnekleşmiş işgücü piyasalarında sendikanın yerini işaret etmektedir. Sendikanın işveren ile iş̧̧inin arasından çekilmesi bir yandan özgürlük olarak algılanırken bir yandan da işçinin haklarını savunacak bir mekanizmanın kalmaması ve işverenin çalışma stillerini istediği gibi esnetebileceği anlamına gelmektedir.

"Bu iş yerinde kariyer imkânınızın olduğunu düşünüyor musunuz ?” sorusuna ise verilen cevaplara ilişkin görüşülen 18 işçinin 18'i de kariyer imkânlarının bulunmadığını, bu durumun aldıkları eğitimin yetersiz olması ile ilgili olduğunu belirtmiştir. Bu durumu T2 firmasında çalışan iş̧̧i (İ) “Kariyer bizim meslekte olmaz.” şeklinde ifade etmiştir. K1 firmasında çalışan tekniker (TEK1) ise bu soruya "Ben teknik ressamım. Böyle bir firmada çalı̧̧arak kariyerimi yükseltiyorum zaten. Bizim için daha da ilerleme şansı yok. Çünkü bizim amirimiz mühendisler. ” cevabını vermiştir. Diğer taraftan, kurumsal firmalarındaki tüm mühendislerin kariyerlerini olumlu devam ettirdikleri yönünde cevaplar verirken, aynı işi yapan taşeron firmalarındaki mühendisler çalıştıkları firmalarda kariyer imkânlarının bulunmadığını belirtmişlerdir. Buna ilişkin T1 firmasında çalışan mühendis (M2) "Her çalışma kariyere bir katkıdır ama bu firmada gelişemem, yükselme firsatım yok. Çünkü çok küçük bir firma gelebileceğim pozisyon proje koordinatörlügü̈, zaten bu pozisyonda çalışan biri var.” şeklinde beyanda bulunmuştur. 


\subsection{3. Ücret Yapısına İlişkin Bulgular}

Yapılan araştırmada ücret memnuniyetini saptayabilmek için, ücretin piyasadaki düzeyi, ücretin düzenli ödenmesi, zam alma sıklığı, özlük hakları ve sosyal yardımlar ile ilgili görüşmecilere sorular sorulmuştur. Tabakalı işgücü piyasası özelliklerine paralel olarak ikincil piyasada çalışan işçi ve mühendislerin ücretlerinin düzenli ödenmediği, bir kaç ay geciktiği ve zam ödemelerinde düzensizlik ve belirsizlik olduğu, zam almanın işverenin takdirine bağlı olarak gerçekleştiği tespit edilmiştir. Diğer taraftan birincil piyasada çalışan işçi ve mühendislerin ücret ve zamlarının düzenli ödendiği tespit edilmiştir. Kurumsal firmalarda çalışan mühendis ve işçiler özlük haklarını alabildiklerini belirtirken, taşeron firmalarda çalışanlar zaman zaman aksama yaşadıklarını beyan etmişlerdir. Tabakalı işgücü piyasası özelliklerine paralel olarak kurumsal firmalarda çalışanlar daha fazla sosyal yardımdan faydalanmaktadır. Özellikle kurumsal firmada proje koordinatörü olarak çalışan üst pozisyondaki mühendislere diğer mühendislerden ayrıcalıklı olarak ev ve/veya araç tahsis edildiği, işçilere ise düzenli yakacak yardımı bildirilmiştir.

Öncelikle "Ne kadar ücret alıyorsunuz?" sorusuna çalışanların çekimser kalması sebebiyle kurumsal firmalardaki insan kaynakları departmanından alınan bilgilere göre ücret ödemelerindeki en alt sınırın işçiler için asgari ücret, teknikerler için 1800-2400TL arası ve mühendisler için 30003500TL olduğuna ilişkin bilgi verilmiştir. Taşeron firmalarda ise işçilere en az asgari ücret, mühendislere ise en az 2000 TL civarı ödeme yaptıkları bildirilmiştir.

"Ücretinizi düzenli alıyor musunuz?" sorusuna ise taşeron firmalarda görüşme yapılan tüm kişiler ücretlerin “düzenli ödenmediğini”, kurumsal firmalarda çalışanlar ise "çok düzenli” ödendiğini ifade etmiştir. T1 firmasında çalışan işçi (İ1) bu konuda "Işse başlarken ayın l'inden birine maaş ödenir dediler ama bu süre hep gecikiyor. Hiç düzenli alamadık “ derken T2 firmasında işçi (İ) "Bizim 2 ay geciktiği bile oluyor. Hatta şuan 1 maaşımız içeride” demiştir. K1 firmasında çalışan işçi (İ3) ise "Ayın birinden birine düzenli yatıyor" ifadesini kullanmıştır. Bu soru başlığında mühendislerin de benzer cevap verdikleri görülmüsşür. Ücret memnuniyetindeki en önemli sorunlardan biri de düzenli ödemelerdir. Çünkü bir çalışanın ücretini düzenli alması, hem kendi hem de bakmakla yükümlü olduğu ailesinin ihtiyaçlarını zamanında karşılayabilmesi anlamına gelir. Bu durum kişinin refah seviyesine katkıda bulunurken aynı zamanda çalışanın motivasyonu ve verimliliğini yükseltmekte aynı zamanda istihdamda süreklilik sağlamaktadır.

Zam alma sıklığı ile ilgili soruya verilen cevaplar "hiç zam almama” ve “ yılda bir kere zam alma" şeklindedir. Buna göre taşeron firmalarda çalışan işçiler zam almadıklarını ve ilerleyen süreçte de zam alıp almayacaklarını bilmediklerini ifade etmişlerdir. T1 firmasında çalışan bir işçi (İ1)'nin ifadesi şu yöndedir: "Ben 4 yıldır bu firmada çalışıyorum, fakat daha hiç zam almadım. Sadece asgari ücrete yapılan zam üstünden aldığımız ücret yükseliyor. Zam istediğimizde patronumuz durumunun kötü olduğunu söylüyor." Taşeron firmada çalışan İşçi (İ1)'in ifadesine göre işçilerin aldıkları zam 
ancak işverenin takdirine bağlı olmaktadır fakat (İ1) işsiz kalmamak için bu ücrette çalışmayı kabul etmiştir. T2 firmasında çalışan işçi (İ) ise zam almama konusunda şu cevabı vermiştir: "Zam alma konusunda, benim bildiğim kadarıyla birkaç yıl aynı firmada çalışınca oluyor. Benim ve iki arkadaşımızın daha 1 yılı dolmadı. Proje sorumlumuz 1 yılı geçtikten sonra zam alacă̆ımızı söylüyor”. Diğer taraftan kurumsal firmada çalışan işçiler düzenli olarak zam aldıklarını beyan etmiştir. K1 firmasında çalışan işçi (İ6) ise net olarak yılda bir kez zam aldıklarını belirtmiştir.

Taşeronda çalışan mühendislerin ise zam alma sıklı̆ğ yönündeki beyanları şu şekildedir: T1 firmasında çalışan mühendis (M1) “Yılda bir zam alıyoruz.” Derken, T2 firmasındaki mühendis (M4) "2 yıldır zam almıyorum" demiştir. Diğer taraftan kurumsal firmada çalışan 15 mühendisin hepsi yılda bir düzenli zam aldıklarını ifade etmiştir.

Ücret yapısı konusundaki bir diğer soru “Özlük haklarınızı alıyor musunuz ?” sorusudur. Kurumsal firmalarda gerek işçi statüsünde gerekse mühendis statüsünde çalışanlar özlük haklarının tamamını alabildiklerini beyan etmişlerdir. K1 firmasında çalışan bir yüksek mühendis (M5) bu soruya şu cevabı vermiştir; "Özlük hakları olarak özel sigortamız var. Ayrıca fazla mesai ücretlerimiz çok düzenli ödeniyor." K2 firmasındaki bir işçi (İ3) bu soruya şöyle cevap vermiştir; "Sigortamız da maaşımız gibi düzenli ödeniyor. Çıkarılan bir arkadaşımızın tazminatı da iki parça halinde düzenli ödendi mesela. Söyledikleri tarihlerde ödediler.” K2 firmasında çalışan tekniker (TEK2) ise bu konuda "Özlük haklarımızı alıyoruz. İstediğim zaman izin kullanabiliyorum. Sigortamız da düzenli" demiştir.

Fakat taşeron firmalarda çalışanlar özlük haklarının alınmasına ilişkin aksaklıklar yaşandığını bildirmiştir. T1 firmasında çalışan işçi (İ4) beyanı şu şekildedir: "Onun ne olduğunu bilmiyorum ama SSK'mız düzenli ödenmiyor. Gecikiyor çoğu zaman. Bir de izin sıkıntı oluyor”. Diğer taraftan yevmiyeli olarak çalışan işçiler sigortalarının yapılmasının bir lütuf olarak görüldügünü beyan etmiştir. T1 firmasındaki mühendis (M1) özlük haklarının alınıp alınmaması konusunda; “Özlük hakları olarak, sigorta, izin, kıdem ve ihbar tazminatımız var. Başka bir şey yok. Sigortamız arada gecikiyor. Burada az mühendis olduğu için benim izin almam da epey sıkıntı oluyor” şeklinde ifade etmiştir.

Görüşmecilerin "Sosyal yardım alıyor musunuz?" sorusuna verilen cevaplardan yola çıkarak kurumsal ve taşeron firma arasındaki belirgin farkl11ıklar olduğu tespit edilmiştir. Bu farklılıklar işgücü piyasasındaki tabakalaşmayı destekler niteliktedir. Her iki kurumsal firmada da mühendis unvanı ile çalışanlar firmadaki pozisyonlarına göre farklı sosyal yardım veya ikramiye almaktadır. K1 firmasında çalışan mühendislerin hepsi yılbaşında bir maaş ikramiye almakta ve ayrıca yol ve yemek masrafları karşılanmaktadır. Diğer taraftan K1 firmasında "Proje Koordinatörü" unvanı ile çalışan bir yüksek mühendis (M4) sosyal yardımlar konusundaki soruya şu cevabı vermiştir: "Sosyal yardım konusunda, yllda bir maaş ikramiye alyyoruz. Ayrıa bana şirket aracı tahsis edildi.” K2 firmasında "Proje Geliştirme Koordinatörü" olarak çalışan bir yüksek mühendis (M7) ise şu şekilde ifade 
etmiştir: "Ben şirketin verdiği aracı kullanıyorum. Ayrıca ailem burada olmadiğı için şirket bana bir ev kiraladı ve kirasını ödüyor”. Yapılan sosyal yardımlar ile bu kurumsal firmalarda çalışan yüksek mühendislerin refah standartları yükselmektedir. Dolayısıyla başka bir iş yerinde çalışmayı düşünmemektedirler. Diğer taraftan K2 firmasındaki bir diğer mühendis (M9) sosyal yardım olarak şunları söylemiştir: "Yılbaşında iki maaş alıyoruz. Özel sigortadan yararlanıyoruz. Anlaşmalı hastanelerde tedavi olabiliyoruz." Aynı firmada (K2) çalışan tekniker (T2) ise bu konuda "sosyal yardım olarak yılbaşında bir maaş ikramiye alıyoruz" demiştir.

Diğer taraftan taşeron firmalarda çalışan mühendislerin yalnızca öğle yemeklerinin karşılandığı belirtilmiştir. Yalnızca T2 firmasında “proje koordinatörü” ünvanı ile çalışan mühendis (M8) bu konuda şu cevabı vermiş̦tir; “ Sosyal yardım olarak yılbaşlarında kuru kumanya ve yakacak yardımı aldım. Onu da iki kere aldım. Düzenli olarak aldığımız bir sosyal yardım yok. Yol parasını ödenmiyor ama öğlen yemeğini işyeri karşıllyor.” Buna göre taşeron firmalarda çalışan proje koordinatörü mühendislere kurumsal firmalarının sunduğu olanaklar sunulmamakta ve sadece düzenli olmayan yardımlar yapılmaktadır.

Görüşmecilerin beyanlarına göre; işgücü piyasasındaki tabakalı yapıyla uyumlu olarak birincil piyasada çalışanların düzenli ücret ve zam almaları, özlük haklarından faydalanabilmeleri, düzenli ikramiye ve sosyal yardım almaları birincil ve ikincil piyasada çalışanlar arasındaki ücret farklılıklarını daha da arttırmaktadır. Birincil piyasada daha yüksek ve düzenli ücret alan ve ücret ekleri ile birlikte daha yüksek giydirilmiş ücret alan çalışanların kurumlarına olan bağlılığı ve verimi artarken istihdamda süreklilik sağlanmaktadır. Diğer taraftan, bu imkânların sağlanılmadığı ikincil piyasadaki firmalarda işçi devri yüksek olacaktır.

\section{SONUÇ}

İşçilerin sahip olduğu heterojen özellikler, işin niteliği ve ücretin yapısı gibi birçok faktör, tüm piyasa koşulları sabitken bile bireylere ödenen ücretin aynı olmamasına ve ücretler arasında farklılıklarının ortaya çıkmasına neden olmaktadır. Bu faktörlerle birlikte işgücü piyasasının tabakalı yapısı aynı niteliğe sahip aynı işi yapan bireyler arasında ücret farklılığına neden olmaktadır. Tabakalaşma teorisine göre firmalar birincil ve ikincil piyasaların içinde yer alarak kendi aralarında ücret, çalışma koşulları, kayıtlı istihdam, kariyer olanağı ve istihdamın sürekliliği açısından farklılık göstermektedir.

İşücü piyasasındaki tabakalı yapının gözlendiği inşaat sektöründe de birincil ve ikincil piyasa özellikleri gösteren kurumsal ve taşeron firmaların ücret politikaları ve çalışma koşullarının birbirinden ayrıldığı gözlenmektedir. İnşaat sektöründeki ücret farklılığına neden olan faktörleri işgücü piyasasındaki tabakalaşma çerçevesinde inceleyen bu çalışmada kurumsal ve taşeron firmalarda çalışan mühendis, tekniker ve işçilerle görüşmeler yapılmıştır. Elde edilen bulgular sonucunda çalışanların aynı işi yapmalarına ve firma içi pozisyonlarının da aynı olmasına rağmen farklı ücret 
aldıkları tespit edilmiştir. Alan araştırmasından elde edilen bulgulara göre inşaat sektöründeki işgücünün özelliklerinden kaynaklı olarak ücret farklılığına neden olan faktörler eğitim ve mesleki tecrübe (ve yaş) olarak ortaya çıkmıştır. Çalışanların mesleki pozisyonları ve aldıkları sosyal yardım ve ikramiyeler de ücretlerini etkileyen bir diğer faktördür. Proje koordinatörü ünvanı ile çalşsan mühendislerin daha yüksek ücret aldığı ve daha ayrıcalıklı sosyal yardımlardan yararlandığı tespit edilmiştir. Sektördeki ücret farklııkları tabakalı işgücü piyasası özelliklerini de ortaya koymaktadır. Birincil piyasada çalışan mühendislerin ve işçilerin eğitim düzeylerinin, yaşlarının ve mesleki tecrübelerinin daha yüksek olduğu, mühendislerin başlangıç ve ortalama ücretlerinin daha fazla olduğu ve daha fazla sosyal yardım aldıkları tespit edilmiştir. Birincil piyasanın aksine ikincil piyasada çalışan işçi ve mühendislerin ücretlerinin düzenli ödenmediği, zam ödemelerinde düzensizlik ve belirsizlik olduğu, kariyer olanaklarını yetersiz görüldüğü ve hafta sonları da çalışıldığı tespit edilmiştir. Bu durum inşaat sektöründeki tabakalı işgücü piyasasının varlı̆̆ını göstermektedir. Diğer taraftan, gerek birincil gerekse ikincil piyasada faaliyet gösteren firmalarda çalışan mühendis ve işçilerin hiçbirinin herhangi bir sendika üyeliği bulunmazken, her iki piyasada çalışan işçiler sendikaya üye olmak istedikleri ifade edilmiştir. İnşaat sektörü, Türkiye'nin en hızlı gelişen ve katma değer yaratan sektörlerinden biri olmakla ile birlikte istihdam yaratma kapasitesi bakımından önem arz etmektedir. Emek yoğun niteliğe sahip olan sektörde farklı vasıf ve niteliğe sahip birçok farklı meslek grubu istihdam edilmektedir. Diğer taraftan kırsal kesimden gelen niteliksiz emeğin istihdam edildiği sektörlerin başında gelmekte olan inşaat sektöründe eğitim istihdam ilişkisi zayıftır. Ana yüklenici ve altyüklenici (taşeron) olarak farklı iş yapma tekniklerinin yer aldığı sektörde düşük ücretli, ucuz maliyetli hizmet üretme kaygısı ve kayıt dışı uygulamalar, küçük ölçekli firmalar ve kurumsallaşmanın yetersiz olması sektördeki tabakalaşmalı yapıyı ortaya çıkarmaktadır. Bu durum aynı niteliğe sahip aynı işi yapan çalışanlar arasındaki ücret farklılıklarına neden olmakta ve uzun dönemde gelir dağılımında adaletsizliğe neden olmaktadır.

\section{KAYNAKÇA}

Ataman, B.C.(1998) “İşssizlik Sorununa Yeni Yaklaşımlar”, Ankara Üniversitesi SBF Dergisi, 53(1): 65

Aydın, E., Hisarciklilar, M. ve İlkkaracan, İ. (2010) "Formal versus Informal Labor Market Segmentation in Turkey in the course of Market Liberalization", Topics in Middle Eastern and African Economies, September, 12:1-43.

Aydın, E. (2009) “Formel ve Enformel Sektör Ücret Farklılıkları: Katmanlı İşgücü Piyasası Kuramının Türkiye Emek Piyasasına Uygulanması”, İTÜ, SBE, İstanbul, Yayınlanmamış Yüksek Lisans Tezi .

Becker, G. (1962) "Investment in Human Capital: A Theoretical Analysis", Journal of Political Economy, 70(5): 9-49. 
Benligiray, S (2003) “3600 Geribildirim Kısa Dönemli Bir Yönetim Modası mıdır?”, Anadolu Üniversitesi İ̇BF Dergisi, (Prof. Dr. Doğan Bayar'in Hatirasina Armağan), 19(1-2): 55-73

Biçerli, K. ve Gündoğan, N. (2008) “Çalışma Ekonomisi”, Bursa: Teknik Kitabevi.

Bozkurt, Ö. ve Bozkurt, İ. (2008) “İş Tatminini Etkileyen İşletme İçi Faktörlerin Eğitim Sektörü Açısından Değerlendirilmesine Yönelik Bir Alan Araştırması”, Doğuş Üniversitesi Dergisi, $9(1): 1-18$

Cain, G. (1975) "The Challenge of dual and Radical Theories of the Labor Market to Orthodox Theory", The American Economic Review, 65(2): 16-22.

Doeringer, P.B. ve Piore, M.J. (1971) “'Internal Labor Markets and Manpower Analysis', Lexington, MA: D.C. Heath and Company.

Durmaz, Ş.(2016) “İşgücü Piyasasında Kadınlar ve Karşılaştıkları Engeller”, AEÜSBED, 2(3): 37-60

Ercan, H. ve Tunal1, I. (1998) "Labor Market Segmentation in Turkey", in Main Characteristics and Trends in the Turkish Labor Market, T. Bulutay (editör), Ankara: TÜIK.

Hudson, K. (2007) "The New Labor Market Segmentation: Labor Market Dualism in the New Economy", Social Science Research, 36(1): 286-312

Işığıçok, Ö. (2011) “Ücret”, Bursa: Marmara Kitabevi Yayınları

Inşaat Sektörü-Ulusal İstihdam Stratejisi (2016), www.uis.gov.tr/media/1423/İnşaat-sektoerueraporu.docx (28.10.2017).

INTES, (2017) “İş̧aat Sektörü Raporu”, Nisan, http://intes.org.tr/content/insaat 2016.pdf (28.10.2017)

Katz, L. (1986) “Efficiency Wage Theories: A Partial Evaluation”, NBER Macroeconomics Annual, 1:235-290.

Kumaş, H., Atalay, Ç. ve Karaalp, H.S. (2014) “Firm Size and Labour Market Segmentation Theory: Evidence from Turkish Micro Data” Procedia - Social and Behavioral Sciences 150 (2014):360 -373 .

Levent, H., Taştı, E. ve Sezer, D. (2004) “İşgücü Piyasasının Katmanlı Yapısı”, Türkiye'de İşgücü Piyasasının Kurumsal Yapısı ve İşsizlik, 27-63, Istanbul: TÜSİAD.

Levitan,S.A., Mangum, G.L. ve Marshall, G. (1976) "Human Resources and Labor Markets", NewYork: Harper-Row Publishers

Lordoğlu, K. ve Özkaplan, N. (2007) “Çalışma İktisadı”, İstanbul: Der Yayınları. 
McNabb,R.(1987) “Testing for Labour Segmentation in Britain”, The Manchester School, 55(3): 257273

Murat, S. ve Şahin, L. (2011) “AB’ye Uyum Sürecinde Genç İşsizliğił”, İstanbul: İTO Yayınları.

San S. (2012) “Türkiye'de Firma Büyüklüğü ve Ücret Farklılıkları İlişkisinin Analizi”, Çalışma ve Toplum 4(35): 214-232.

Topalhan, T. (2013) “Ücret Teorileri ve Ücret Politikaları”, İstanbul: Meridyen Yayınları.

TÜIK (2015) Kazanç Yapısı Araştırması 2014, Haber Bülteni, Sayı: 18861 http://www.tuik.gov.tr/PreHaberBultenleri.do?id=18861 , (20.07.2017).

TÜIK (2017a), Dönemsel Gayrisafi Yurtiçi Hasıla (2009=100), http://www.tuik.gov.tr/PreTablo.do?alt_id=1105, (19.09.2017)

Urhan, B. ve Selamoğlu, A. (2008) "İşçilerin Sendikalara Yönelik Tutum ve Davranışları; Kocaeli Örneği”, Çalışma ve Toplum, 3(18): 171-197. 